Ambiente \& Água - An Interdisciplinary Journal of Applied Science
ISSN 1980-993X - doi:10.4136/1980-993X
www.ambi-agua.net
E-mail: ambi.agua@gmail.com

\title{
Removal of benzene and toluene from a refinery waste air stream by water sorption and biotrickling filtration
}

doi:10.4136/ambi-agua.1764

Received: 24 Sep. 2015; Accepted: 13 Oct. 2015

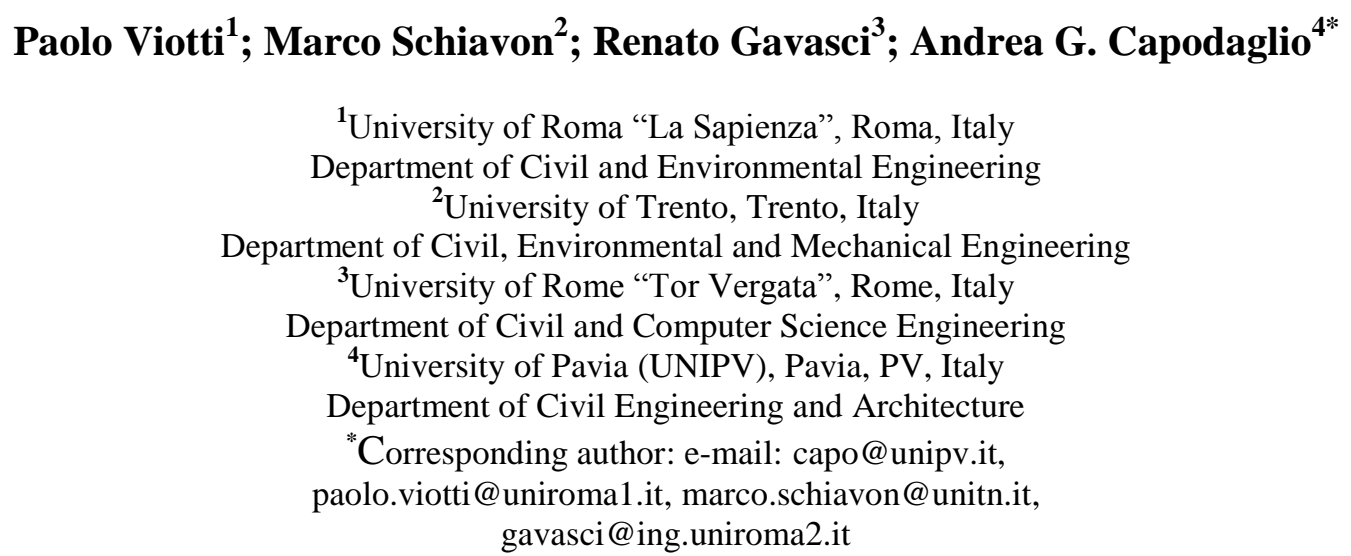

\begin{abstract}
The paper presents the results of an analysis of a two-stage pilot plant for the removal of toluene and benzene from the exhaust air of an industrial wastewater treatment plant (WWTP). The two-stage air process combines a water scrubber and a biotrickling filter (BTF) in sequence, and treats air stripped from the liquid phase compartments of the WWTP. During the experimental period, the pilot plant treated an airflow of $600 \mathrm{Nm}^{3} \mathrm{~h}^{-1}$. Average concentrations of the waste air stream entering the water scrubber were $10.61 \mathrm{mg} \mathrm{Nm}^{-3}$ benzene and $9.26 \mathrm{mg} \mathrm{Nm}^{-3}$ toluene. The water scrubber obtained medium-high removal efficiencies (averages $51 \%$ and $60 \%$, for benzene and toluene, respectively). Subsequent passage through the BTF allowed a further reduction of average concentrations, which decreased to $2.10 \mathrm{mg} \mathrm{Nm}^{-3}$ benzene and to $0.84 \mathrm{mg} \mathrm{Nm}^{-3}$ toluene, thereby allowing overall average removal efficiencies (REs) of $80 \%$ and $91 \%$ for benzene and toluene, respectively. Results prove the benefits obtained from a combination of different removal technologies: water scrubbers to remove peak concentrations and soluble compounds, and BTFs to remove compounds with lower solubility, due to the biodegradation performed by microorganisms.
\end{abstract}

Keywords: absorption, air treatment, scrubber, volatile organic compounds.

\section{Remoção de benzeno e tolueno de um efluente de refinaria por absorção e filtração "biotrickling"}

\section{RESUMO}

Este estudo apresenta os resultados obtidos em uma instalação piloto de duplo estágio para a remoção de tolueno e benzeno no efluente de uma estação de tratamento de águas residuárias (ETAR) industriais. A instalação de tratamento de ar de duplo estágio combina um scrubber de água com um filtro biotrickling (BTF) e trata o ar despojado dos compartimentos 
da ETAR. Durante a atividade experimental, a instalação piloto tratou um fluxo de ar de $600 \mathrm{Nm}^{3} \mathrm{~h}^{-1}$. As concentrações médias do fluxo de ar residual que entraram no scrubber foram 10,61 e 9,26 $\mathrm{mg} \mathrm{Nm}^{-3}$ de benzeno e tolueno, respectivamente. O scrubber permitiu obter eficiências de remoção (ER) média-altas (valores máximos de $84 \%$ e $92 \%$, respectivamente). A passagem pelo BTF permitiu uma redução adicional das concentrações médias, que diminuíram até $2,10 \mathrm{mg} \mathrm{Nm}^{-3}$ de benzeno e $0,84 \mathrm{mg} \mathrm{Nm}^{-3}$ de tolueno. Isto permitiu a obtenção de uma ER média global de $80 \%$ e $91 \%$ de benzeno e tolueno, respectivamente. Esses resultados comprovam os benefícios associados a uma combinação de diferentes tecnologias de remoção: scrubber de água para remover as concentrações máximas e compostos solúveis, e BTF para remover também compostos com baixa solubilidade, graças à biodegradação realizada por microorganismos.

Palavras-chave: absorção, compostos orgânicos voláteis, scrubber, tratamento de ar.

\section{INTRODUCTION}

Benzene and toluene are typical components of oil and its derivatives. Such compounds are abundantly present in refinery wastewater as well as in wastewaters from chemical and petrochemical industries. Due to their volatility, and to the liquid-air exchanges occurring, for example, in aerated or vigorously mixed tanks, benzene and toluene are also present in air emissions from wastewater treatment plants (WWTPs) of these industries, as well as in emissions from other processes that use benzene and toluene as solvents, thinners or degreasers (Raboni et al., 2013). On the other hand, it has been observed that with specific biological reactors, and in the presence of specially-acclimated biomass, these compounds can be removed extremely quickly from waste streams, with negligible stripping from the liquid to air phase, even in the presence of continuous aeration (Capodaglio et al., 2010). These compounds are also found in the exhaust air of mechanical-biological waste treatment plants (Schiavon et al., 2015a), in landfill biogas (Raboni et al., 2015), and in vehicles' exhaust gases (Faber et al., 2013).

Following inhalation exposure, toluene may induce adverse health effects, acute and/or chronic: the former include nausea, fatigue, headaches and cardiac arrhythmia. Irritation of respiratory systems, depression and other central nervous system disturbances, and effects on kidneys and liver were reported as the main chronic effects (US-EPA, 2015a). Inhalation of benzene at high concentrations (acute exposure) may result in neurological dysfunctions such as drowsiness, dizziness, headaches, and unconsciousness. Unlike toluene, benzene is a demonstrated human carcinogen. Long-term exposure to this compound may provoke leukemia (US-EPA, 2015b). Due to the toxic behavior of these compounds, it is essential to minimize their release into the environment and, particularly, into the atmosphere, in order to protect workers and the general public health.

Traditionally, gaseous exhausts containing benzene and toluene may be treated by means of physical, physical-chemical and thermal processes, such as condensation, absorption/ adsorption, incineration or catalytic oxidation (Kennes and Veiga, 2010). Such systems allow high removal efficiencies (REs), but are characterized by high investment and operating costs (as an example, the costly catalytic removal in car exhausts). One exception is represented by water absorption, a low-cost technology; when treating volatile organic compounds (VOCs); however, water scrubbing may only be effective as a pre-treatment for removal of VOCs at medium-high concentrations, due to the generally low solubility of these substances in water (Urbini et al., 2014).

Two biologically-based gas treatment technologies have received increasing consideration lately: biofiltration, and biotrickling filtration. Both of them are low-cost, 
energy-efficient options originally applied for odor removal from diluted waste air streams in municipal WWTPs and mechanical-biological treatment facilities such as composting, bio-drying and biostabilization. These technologies showed encouraging results also in the treatment of several industrial air streams containing a variety of compounds, including VOCs, and nitrogen- and sulfur-based compounds (Schiavon et al., 2015b; Torretta et al., 2013). Biological technologies for air purification demonstrated the capacity to treat air flows with low concentrations of poorly soluble contaminants.

Compared to biofilters, operating solely in the gas phase, biotrickling filters (BTFs) have several advantages: smaller volume and lower surface requirements, durability of packing material (usually > 10 years), lower pressure drops (due to a higher porosity of the packing material and to an improved control of excess biomass), easier control of $\mathrm{pH}$ and temperature, the possibility of conveying and releasing the treated gas at higher levels, with positive consequences on plume atmospheric dispersion (Schiavon et al., 2015b). Due to these value-adding features, BTFs are considered to be more effective systems that may usefully replace biofilters, and can be used in combination with other removal technologies, paving the way to different combined air-treatment process configurations.

This paper presents the results of a two-stage process pilot application, combining water absorption with biotrickling filtration for the treatment of exhaust air stripped from the liquid process units of an oil refinery WWTP. The latter is fed by wastewaters highly contaminated with benzene, toluene and other by-products of oil processing. The results are discussed in terms of REs and benzene and toluene concentrations, measured upstream and downstream of each process stage during a trial period of 60 days.

\section{MATERIALS AND METHODS}

An illustration of the two-stage pilot plant tested herein is presented in Figure 1, and is composed of:

A water scrubber filled with Pall Rings ( $5 \mathrm{~cm}$ diameter) with the following features:

- column diameter: $1.6 \mathrm{~m}$;

- packing height: $1.6 \mathrm{~m}$;

- packing volume: $4.0 \mathrm{~m}^{3}$.

A BTF filled with blue mussel shells, exhibiting high buffering power, useful to prevent $\mathrm{pH}$ decrease and thus potential inhibition of bacterial activity. The main features of the BTFs are:

- height of filter: $1.0 \mathrm{~m}$;

- total volume: $6.0 \mathrm{~m}^{3}$.

The airflow treated by the two-stage plant is $600 \mathrm{Nm}^{3} \mathrm{~h}^{-1}$. Influent air temperature during the test period ranges between $24-28^{\circ} \mathrm{C}$ (average $26^{\circ} \mathrm{C}$ ). For water conservation purposes, liquid WWTP effluent is used as scrubber unit's wash water and as make-up water for both stages. An additional advantage of this setup is that the BTF is hence provided with sufficient nutrients to support VOC biodegradation by microorganisms. Furthermore, the WWTP effluent contains a few microorganisms acclimated to VOCs, which are consequently fed to the BTF. 


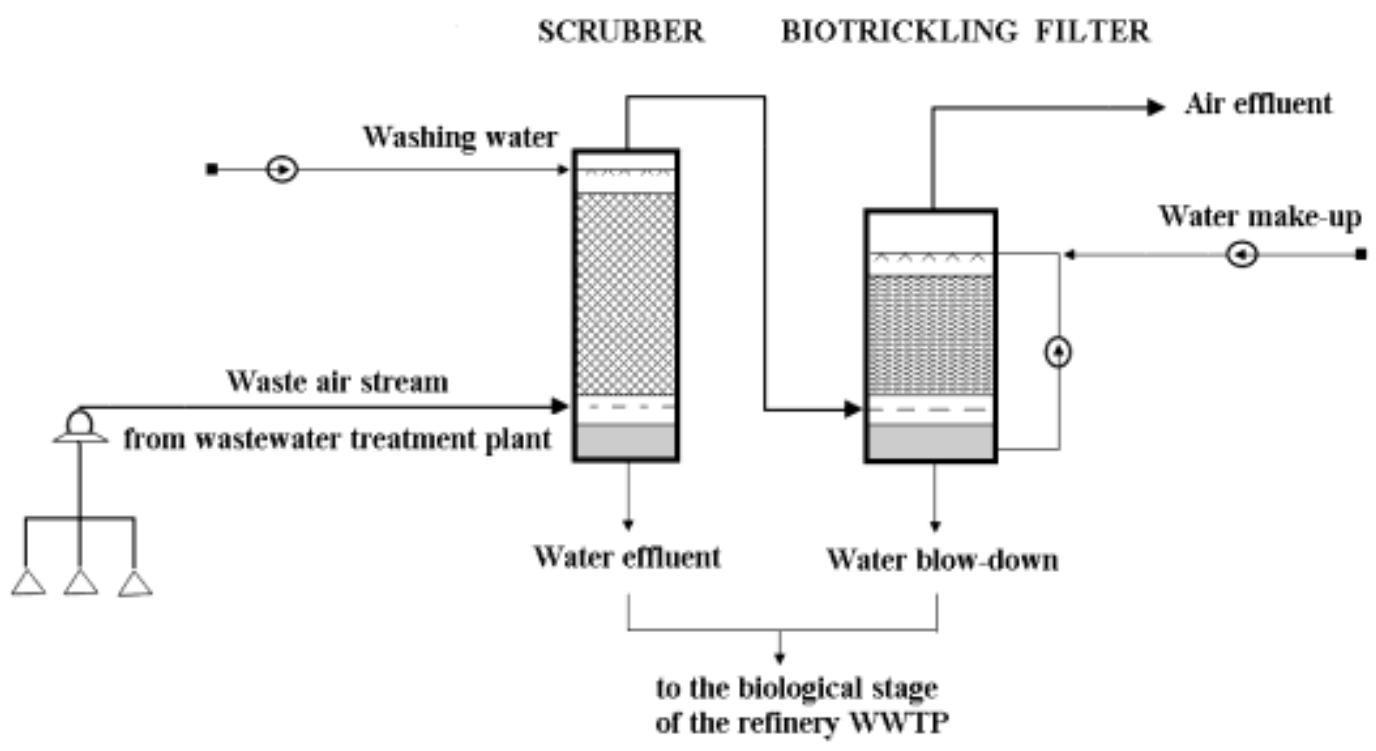

Figure 1. Flow diagram of the two-stage pilot plant.

The flow rate of the wash water to the scrubber is $2 \mathrm{~m}^{3} \mathrm{~h}^{-1}$, while the BTF is fed with a water flow of $0.9 \mathrm{~m}^{3} \mathrm{~h}^{-1}$. During the initial operational period of the pilot air treatment plant (start-up phase), a selected inoculum of microorganisms was inserted into the BTF in order to achieve faster establishment of full operating conditions with a properly functional bacterial population.

The air treatment system was run continuously for a 60 day period. A sampling campaign was carried out for the last 30 consecutive days, after achieving steady operating conditions. During this period, 30 air sample triplets (1 triplet per day) were taken upstream and downstream of the water scrubber, and downstream of the BTF, by using sorbent tubes with SKC sample pumps (SKC Ltd, UK). Samples were then desorbed and analyzed by Gas Chromatography-Mass Spectrometry (GC-MS) in order to determine benzene and toluene concentrations. Flow rate $(Q)$ and temperature $(T)$ were measured by means of a Delta Ohm HD 2303.0 Hot Wire Anemometer, equipped with AP471 S1 temperature probe (Delta Ohm Srl, Italy).

Table 1 summarizes the main physical-chemical properties of benzene and toluene. Benzene, an aromatic hydrocarbon, is a natural constituent of crude oil, and one of the most elementary petrochemicals. As shown by the values in the table below, benzene evaporates into air very quickly, and dissolves only slightly in water. Being classified as LNAPL (Light, Non-Acqueous Phase Liquid), benzene will float on top of water. Toluene (also called Metylbenzene) is also an aromatic hydrocarbon, less volatile than benzene, and mostly water-insoluble (solubility is less than $1 / 3$ that of benzene).

Table 1. Physical-chemical properties of benzene and toluene (Lawrence, 2006).

\begin{tabular}{|c|c|c|c|c|c|c|}
\hline Substance & Formula & $\underset{(-)}{\text { Mol. Wgt. }}$ & $\begin{array}{l}\text { Vapor Pressure } \\
(\mathrm{Pa}) \text { at } 20^{\circ} \mathrm{C}\end{array}$ & $\begin{array}{l}\text { Water solubility } \\
\left(\mathrm{mg} \mathrm{L}^{-1}\right) \text { at } 25^{\circ} \mathrm{C}\end{array}$ & $\begin{array}{c}\log \mathbf{K}_{\mathrm{ow}} \\
\text { octanol/water } \\
\text { partition coeff. } \\
(-)\end{array}$ & $\begin{array}{c}\text { Henry's Law } \\
\text { Constant } \\
\left(\mathrm{kPa} \mathrm{m}^{3} \mathrm{~mol}^{1}\right) \\
\text { at } 25^{\circ} \mathrm{C}\end{array}$ \\
\hline Benzene & C6H6 & 78 & 1,010 & 1,780 & 2.13 & 0.557 \\
\hline Toluene & C7H8 & 92 & 2,900 & 531 & 2.73 & 0.660 \\
\hline
\end{tabular}




\section{RESULTS AND DISCUSSION}

Figure 2 shows inlet and outlet concentrations of benzene (Fig. 2a) and toluene (Fig. 2b), at the inlet and outlet of the water scrubber. Inlet contaminants' concentrations are characterized by high variability (benzene range: $0.41-56.36 \mathrm{mg} \mathrm{Nm}-3$; toluene range: 1.68-22.8 $\mathrm{mg} \mathrm{Nm}^{-3}$ ), as often occurs in real-life conditions, even in steady-state operation. During the period of observation, temperature of the BTF circulation water was between 22 $25^{\circ} \mathrm{C}$, and its $\mathrm{pH}$ varied between 7.4 and 7.6. The stability of $\mathrm{pH}$ can be ascribed to the buffering effect of the calcium carbonate of the blue mussel shells forming the packing material.

Overall, the first-step scrubber treatment achieved medium-high REs of the two contaminants, by reason of their solubility levels in water (benzene: $1,780 \mathrm{mg} \mathrm{L}^{-1}$; toluene: $531 \mathrm{mg} \mathrm{L}^{-1}$ ). Interestingly, toluene seems to be more easily removed in this step compared to benzene, in spite of the latter higher water solubility. This is explainable considering that toluene is more easily biodegradable than benzene, as reported in several studies: Aronson et al. (1999) estimated biodegradation constant rates for both compounds at $20^{\circ} \mathrm{C}$, resulting in $0.096 \mathrm{dr}$ for benzene and $0.2 \mathrm{~d}^{-1}$ for toluene; Chang et al. (1993) reported that bacteria that are able to degrade toluene are also able to biodegrade benzene, but show a preference for toluene when the two compounds are present together; as a result, benzene is degraded more slowly. Otenio et al. (2005) demonstrated that Pseudomonas putida degrades toluene more slowly when this is present in a mixture of VOCs than in the case of toluene alone, explaining the inhibition of toluene biodegradation due to the presence of benzene. Wash water used in the scrubber in this application was WWTP effluent; therefore it contained small concentrations of bacteria that, in time, could colonize the scrubber that worked not just as a pure physical absorption system, but also, in part, as a bioreactor itself.
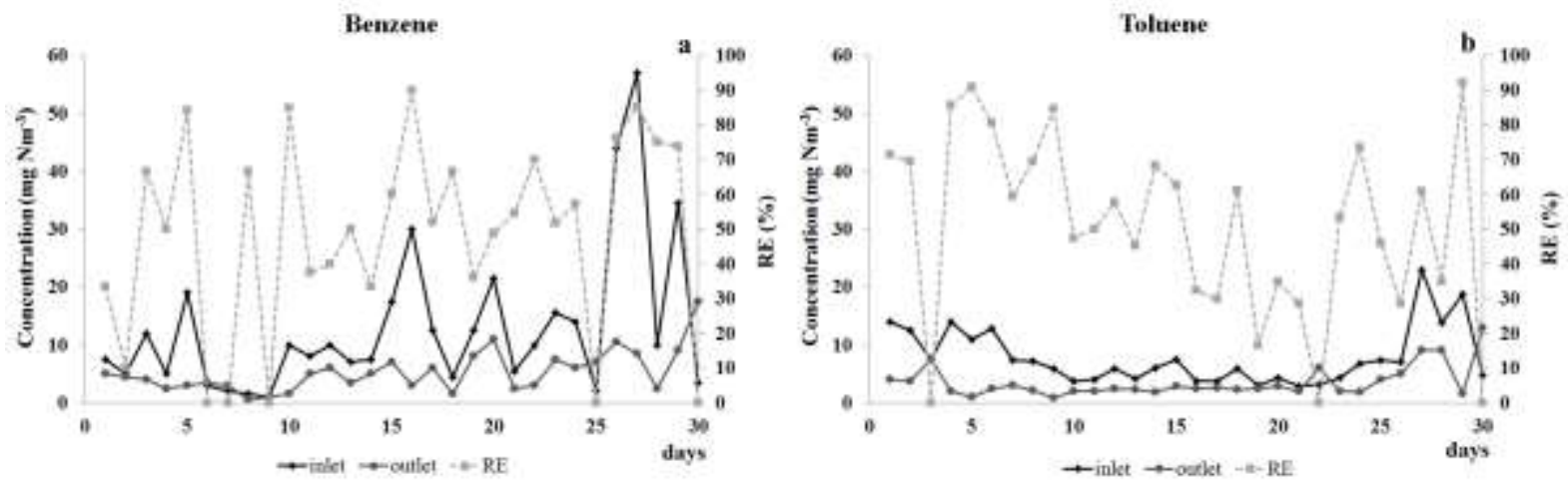

Figure 2. Performance of the water scrubber in removing benzene (left) and toluene (right).

Due to the high variability of the inlet concentrations, RE of the water scrubber varied greatly: from 0 to $84 \%$ for benzene and from 0 to $92 \%$ for toluene, generally increasing with cumulative operation time. In all cases, outlet concentrations were mostly limited to values lower than $10 \mathrm{mg} \mathrm{Nm}^{-3}$ for both compounds, except for two single peak concentrations (benzene $17.2 \mathrm{mg} \mathrm{Nm}^{-3}$; toluene $12.4 \mathrm{mg} \mathrm{Nm}^{-3}$ ). This behavior is consistent with a mixed physical-absorption/biological removal operation.

Figure 3 shows the performance of the BTF in removing benzene (Fig. 3a) and toluene (Fig. 3b) downstream of the scrubber. In this case REs are more stable, achieving final concentrations at the BTF outlet lower than $5 \mathrm{mg} \mathrm{Nm}^{-3}$ for both compounds. 

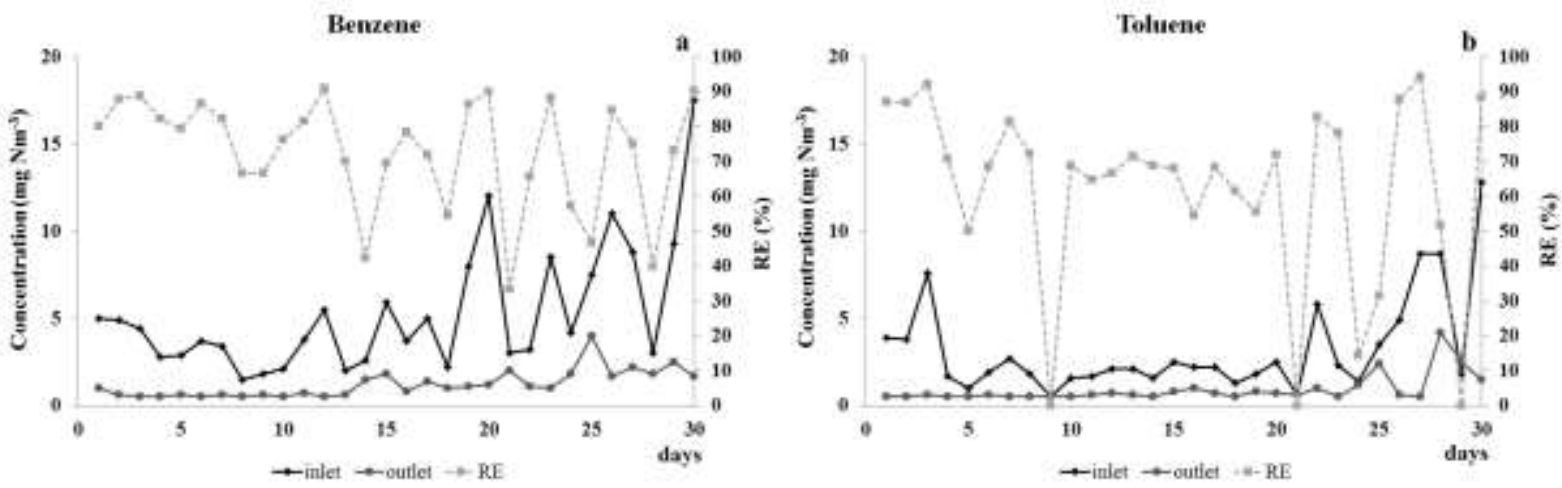

Figure 3. Performance of the BTF in removing benzene (left) and toluene (right).

Figure 4 shows the outcome of a statistical elaboration of the data collected. The average concentrations of the waste air stream entering the scrubber are $10.61 \mathrm{mg} \mathrm{Nm}^{-3}$ benzene and $9.26 \mathrm{mg} \mathrm{Nm}^{-3}$ toluene. At the outlet of the scrubber unit, the average concentrations decrease to $5.25 \mathrm{mg} \mathrm{Nm}^{-3}$ benzene and to $3.66 \mathrm{mg} \mathrm{Nm}^{-3}$ toluene, determining average REs of $51 \%$ and $60 \%$ for benzene and toluene respectively, while maximum punctual values observed were $84 \%$ and $92 \%$. The second-stage treatment occurring in the BTF further lowered the average concentrations of the two VOCs, which decreased to $2.10 \mathrm{mg} \mathrm{Nm}^{-3}$ benzene and to $0.84 \mathrm{mg}$ $\mathrm{Nm}^{-3}$ toluene, thereby obtaining average process REs of $60 \%$ and $77 \%$ for benzene and toluene, respectively. Overall, the entire two-stage process determined final average REs of $80 \%$ for benzene and $91 \%$ for toluene.

The results prove that the combined process is capable of achieving average effluent gaseous concentrations of benzene below $3.0 \mathrm{mg} \mathrm{Nm}^{-3}$, and even lower concentrations of toluene, down to less than $1 \mathrm{mg} \mathrm{Nm}^{-3}$. These same tests have confirmed biodegradation of benzene occurs with more difficulty, compared to toluene.

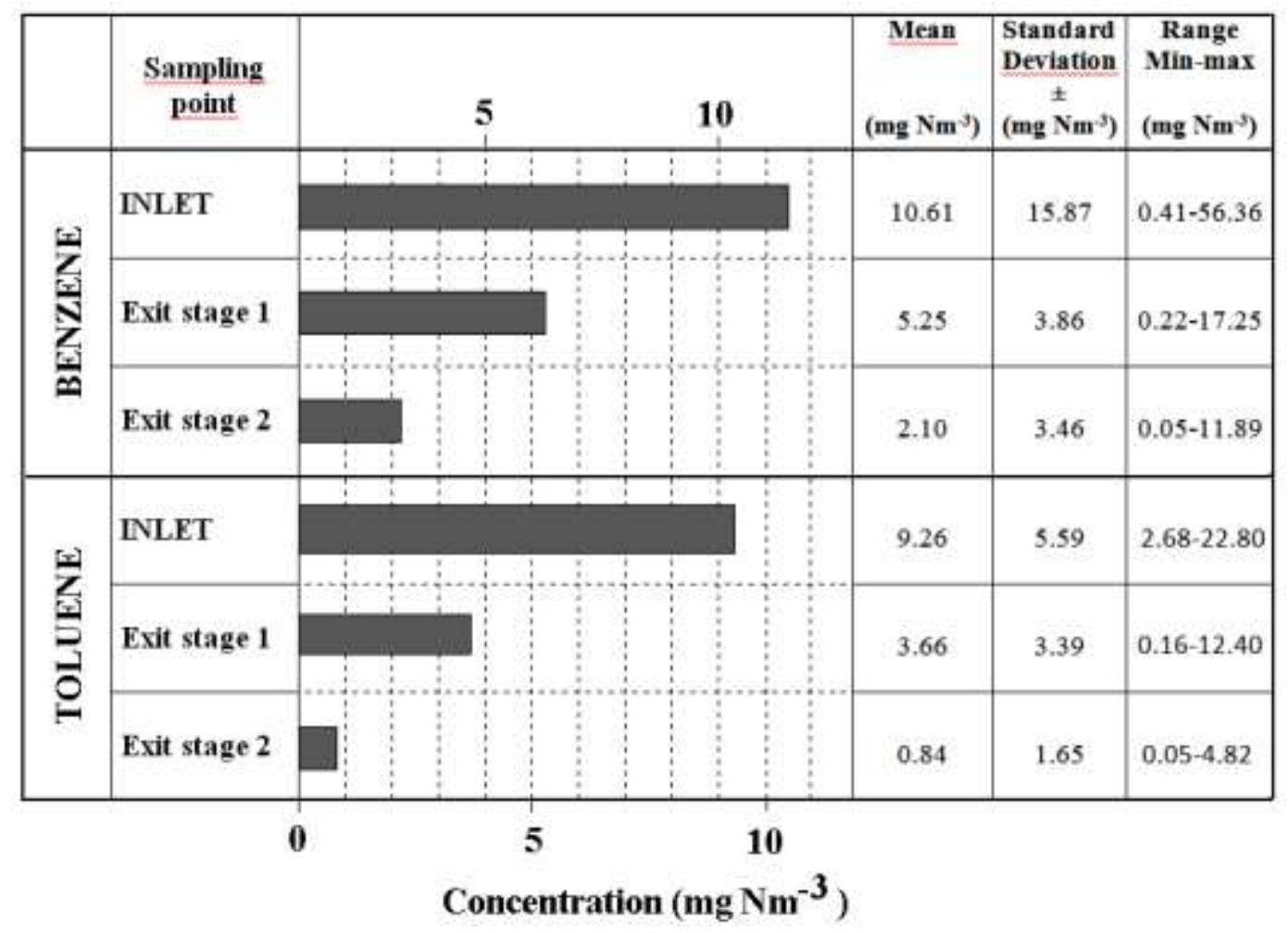

Figure 4. Performance of the process train as a whole and as single stages, evaluated on a statistical basis. 


\section{CONCLUSIONS}

Results obtained during this pilot treatment test to remove VOC's (toluene and benzene) from the gaseous effluent of an oil-refinery WWTP, with application of a combined process (water scrubber plus biotrickling filtration), demonstrated the benefits derived from a proper combination of two different removal technologies. The two-stage process treated average concentrations of $0.61 \mathrm{mg} \mathrm{Nm}^{-3}$ and $9.26 \mathrm{mg} \mathrm{Nm}^{-3}$ (benzene and toluene, respectively), with a high daily variability in the polluted stream, varying in the ranges $0.41-56.36 \mathrm{mg} \mathrm{Nm}^{-3}$ and 2.68-22.8 $\mathrm{mg} \mathrm{Nm}^{-3}$ (benzene and toluene, respectively). The first stage of the combined removal system (water scrubber) showed a limited removal of contaminants peak concentrations, with average REs of $51 \%$ for benzene and $60 \%$ for toluene. The second stage (BTF) process allowed an additional reduction of average concentrations to $<3 \mathrm{mg} \mathrm{Nm} \mathrm{Nm}^{-3}$ benzene and $<1 \mathrm{mg} \mathrm{Nm}^{-3}$ toluene; this brought overall REs to $80 \%$ and $91 \%$ for benzene and toluene, respectively.

The results prove the ability of biological technologies (especially BTFs) to remove low solubility compounds from air streams, mostly due to the biodegradation performed by microorganisms. Coupling traditional absorption processes with biotrickling filtration can lead to interesting results and optimize an air treatment process, especially in the case of gaseous streams containing multiple pollutants with fluctuating concentrations and different water solubility and physical properties.

\section{ACKNOWLEDGEMENTS}

The Authors wish to acknowledge Air Clean S.r.l. (Rho, Milan, Italy) for its onsite technical support.

\section{REFERENCES}

ARONSON, D.; CITRA, M.; SHULER, K.; PRINTUP, H.; HOWARD, P. H. Aerobic biodegradation of organic chemicals in environment media: a summary of field and laboratory studies. Final Report SRC TR 99.002. Athens: USEPA, 1999. 163 p.

CAPODAGliO, A. G.; SUIDAN, M.; VENOSA, A. D.; CALlEGARI, A. Efficient degradation of MtBE and other gasoline-originated compounds by means of a biological reactor of novel conception: two case studies in Italy and the USA. Water Science $\boldsymbol{\&}$ Technology, v. 61, n. 3, p. 807-812, 2010. http://dx.doi.org/10.2166/wst.2010.854

CHANG, M.; VOICE, T. C.; CRIDDLE, C. S. Kinetics of competitive inhibition and cometabolism in the biodegradation of benzene, toluene, and $p$-xylene by two Pseudomonas isolates. Biotechnology and Bioengineering, v. 41, n. 11, p. 1057-1065, 1993.

FABER, J.; BRODZIK, K.; GOLDA-KOPEK, A.; LOMANKIEWICZ, D. Benzene, toluene and xylenes levels in new and used vehicles of the same model. Journal of Environmental Sciences, v. 25, n. 11, p. 2324-2330, 2013. http://dx.doi.org/10.1016/S1001-0742(12)60333-7

KENNES, C.; VEIGA, M. C. Technologies for the abatement of volatile organic and inorganic compounds. Chemical Engineering Transactions, v. 23, p. 1-6, 2010. 
LAWRENCE, S. J. Description, Properties, and Degradation of Selected Volatile Organic Compounds Detected in Ground Water - A Review of Selected Literature. Reston: USGS, 2006. 62 p.

OTENIO, M. H.; LOPES DA SILVA, M. T.; OLIVEIRA MARQUES, M. L.; ROSEIRO, J. C.; BIDOIA, E. D. Benzene, Toluene and Xylene biodegradation by Pseudomonas putida CCMI 852. Brazilian Journal of Microbiology, v. 36, n. 3, p. 258-261, 2005. http://dx.doi.org/10.1590/S1517-8382200500030001

RABONI, M.; TORRETTA, V.; VIOTTI, P.; URBINI, G. Experimental plant for the physical-chemical treatment of groundwater polluted by municipal solid waste (MSW) leachate, with ammonia recovery. Revista Ambiente \& Água, v. 8, n. 3, p. 22-32, 2013. http://dx.doi.org/10.4136/ambi-agua.1250

RABONI, M.; TORRETTA, V.; URBINI, G.; VIOTTI, P. Automotive shredder residue: a survey of the hazardous organic micro-pollutants spectrum in landfill biogas. Waste Management and Research, v. 33, n. 1, p. 48-54, 2015. http://dx.doi.org/10.1177/0734242X14559300

SCHIAVON, M.; SCAPINELLO, M.; TOSI, P.; RAGAZZI, M.; TORRETTA, V.; RADA, E. C. Potential of non-thermal plasmas for helping the biodegradation of volatile organic compounds (VOCs) released by waste management plants. Journal of Cleaner Production, v. 104, p. 211-219, 2015a. http://dx.doi.org/10.1016/j.jclepro.2015.05.034

SCHIAVON, M.; RAGAZZI, M.; RADA, E. C.; TORRETTA, V. Air pollution control through biotrickling filters: A review on operational aspects and expected performance. Critical Reviews in Biotechnology, 2015b, in press.

TORRETTA, V.; RABONI, M.; COPELLI, S.; CARUSON, P. Application of multi-stage biofilter pilot plants to remove odor and VOCs from industrial activities air emissions. WIT Transactions on Ecology and the Environment, v. 176, p. 225-233, 2013.

URBINI, G.; VIOTTI, P.; GAVASCI, R. Attenuation of methane, PAHs and VOCs in the soil covers of an automotive shredded residues landfill: A case study. Journal of Chemical and Pharmaceutical Research, v. 6, n. 11, p. 618-625, 2014. http://jocpr.com/vol6iss11-2014/JCPR-2014-6-11-618-625.pdf

UNITED STATES. Environmental Protection Agency - US-EPA. Air Toxic Web Site. Toluene. 2015a. Available in: http://www.epa.gov/airtoxics/hlthef/toluene.html. Access: Sep. 2015.

UNITED STATES. Environmental Protection Agency - US-EPA. Air Toxic Web Site. Benzene. 2015b. Available in: http://www.epa.gov/airtoxics/hlthef/benzene.html. Access: Sep. 2015. 